\title{
Potentiometric Determination of Stability Constants of Sulphathiazole and Glycine-Metal Complexes
}

\author{
Awad A. Al-Rashdi ${ }^{*}$, A. H. Naggar², O. A. Farghaly'2, H. A. Mauof ${ }^{3}$, A. A. Ekshiba ${ }^{3}$ \\ ${ }^{1}$ Chemistry Department, Al-Qunfudah Center for Scientific Research (QCSR), Al-Qunfudah University College, Um Al-Qura \\ University, Al-Qunfudah, Saudi Arabia \\ ${ }^{2}$ Department of Chemistry, Faculty of Science, Al-Azhar University, Assiut, Egypt \\ ${ }^{3}$ Department of Chemistry, Faculty of Science, Sebha University, Sebha, Libya \\ Email: ^aarashdi@uqu.edu.sa
}

How to cite this paper: Al-Rashdi, A.A. Naggar, A.H., Farghaly, O.A., Mauof, H.A. and Ekshiba, A.A. (2018) Potentiometric Determination of Stability Constants of Sulphathiazole and Glycine-Metal Complexes. American Journal of Analytical Chemistry, 9, 99-112.

https://doi.org/10.4236/ajac.2018.93009

Received: November 24, 2017

Accepted: February 27, 2018

Published: March 2, 2018

Copyright (C) 2018 by authors and Scientific Research Publishing Inc. This work is licensed under the Creative Commons Attribution International License (CC BY 4.0).

http://creativecommons.org/licenses/by/4.0/

\begin{abstract}
Binary and ternary complexes of (Fe(III), $\mathrm{Pb}$ (II), $\mathrm{Co}(\mathrm{II}), \mathrm{Al}(\mathrm{III}), \mathrm{La}(\mathrm{III}), \mathrm{Sr}$ (II), $\mathrm{Cr}(\mathrm{III}), \mathrm{Ti}(\mathrm{II})$ and $\mathrm{Zr}(\mathrm{II})$ ) with sulphathiazole (as primary ligand) and amino acid glycine (as secondary ligand) have been studied potentiometrically at $25^{\circ} \mathrm{C} \pm 0.1^{\circ} \mathrm{C}$ and $\mathrm{I}=0.1 \mathrm{M} \mathrm{NaClO}_{4}$ in $25 \%(\mathrm{v} / \mathrm{v})$ pure ethanol-water medium. Although there are many methods available to study the stability of metal-ligand complexes, $\mathrm{pH}$-metry is most frequently used. In extension of our study on solution equilibria, we used Calvin-Bjerrum method for the calculation of stability constants. Stoichiometries and stability constants of binary systems containing the above metal ions in a 1:1 and 1:2 and/or 1:3 ratios were also determined to compare the effect of the secondary ligand on (1:1) Metal:Sulphathiazole system. The protonation constants of the complexes were evaluated for the system M:Sulphathiazole:Glycine $=1: 1: 1$. The order of stability of the binary and ternary complexes was examined. It was found that glycine adds preferably [M-Sulfathiazole] rather than to the aqueous complexes of metal ions. In all cases 1:1:1 complex was formed.
\end{abstract}

\section{Keywords}

Potentiometry, Glycine, Sulphathiazole, Ternary Complexes

\section{Introduction}

Sulphonamide drugs have been used clinically since the 1930s in human medicine and livestock production [1] [2]. The medical effect of sulphonamides is to prevent bacterial growth by acting as a competitive inhibitor of dihydropteroate 
synthase (DHPS) during folate synthesis [3] [4] [5]. The metal chelates of sulphonamides have been found to be more potent bacteriostatic agents than the parent drugs themselves [6]. Sulphathiazole (4-amino-N-(1,3-thiazol-2-yl) benzenesulfonamide, STZ) is one of the first sulfonamides used in humans after sulfa drug discovery, STZ structure is shown below:

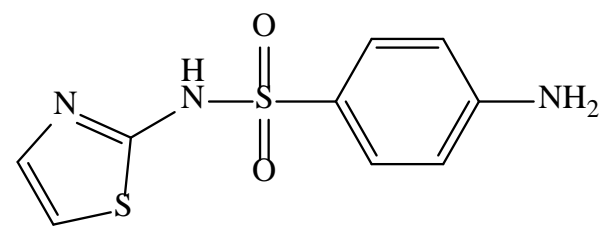

Due to its high toxicity, it is used with other sulfonamides such as sulfabenzamide and sulfacetamide in preparations for the topical treatment of vaginal infections. It is also used in combination with other drugs in the treatment of skin infections [7] [8]. Many metal complexes of STZ are reported in the literature. Some examples are the Co(II)-STZ [9] [10], Pt(II)-STZ [11], Hg(II)-STZ [12], Ag(I)-STZ [13]. Investigation of the binary and ternary complexes of STZ may, therefore, help understand the driving forces leading to the formation of mixed ligand complexes commonly found in biological systems.

The potentiometric method has been used extensively in many branches of solution chemistry. Great attention has been paid to the use of potentiometric methods in the study of binary and ternary complexes of transition metals with molecules of biological and pharmaceutical interest [14] [15] [16]. The importance of potentiometric methods as the most accurate and widely applicable technique in studies related to the ionic equilibrium of different complexes [17]. It should be noted that the presence of metal ions in biological fluids could have a significant effect on the therapeutic action of such organic compounds [18].

As a continuation of our research into binary and ternary complexes of biological significance [19] [20] [21], the present article brings a complete potentiometric and conductometric studies on binary and ternary complexes formed between different metal ions ( $\mathrm{Fe}(\mathrm{III}), \mathrm{Pb}(\mathrm{II}), \mathrm{Co}(\mathrm{II}), \mathrm{Al}(\mathrm{III}), \mathrm{La}(\mathrm{III}), \mathrm{Sr}(\mathrm{II})$, $\mathrm{Cr}(\mathrm{III}), \mathrm{Th}(\mathrm{IV}), \mathrm{Ti}(\mathrm{II})$ and $\mathrm{Zr}(\mathrm{II})$ ) with sulphathiazole (as primary ligand) and amino acid glycine (as secondary ligand). Potentiometric titrations curves, conductometric titration curves and distribution curves of formed binary and ternary complexes were constructed. The obtained curves were used in calculating stability constants of formed binary and ternary complexes.

\section{Experimental}

\subsection{Apparatus}

All the potentiometric measurements were carried out on $\mathrm{pH}$-meter model ELE international, using combined glass electrode (accurate total $0.01 \mathrm{pH}$ units). Conductometric titration measurements were carried out using conductivity meter model 4320, Jenway, using an immersion cell. Before and after each titra- 
tion, the electrode was calibrated using standard buffer $\mathrm{pH} \approx 4.01, \mathrm{pH} \approx 7.00$ and $\mathrm{pH} \approx 9.00$.

\subsection{Materials and Methods}

All the reagents were of analytical grade. Pure ethanol and bidistilled water were used for the preparation of the solutions. Sulphathiazole (4-amino-N-(1,3-thiazol-2-yl) benzenesulfonamide, STZ) was purchased from Sigma Chemical Company (USA). The salts of metallic nitrates (BDH, U.K, GENEVA or INDIA) will be prepared. The aqueous metal ion solution was standardized according to a well-known method [22]. Standard solutions of $0.1 \mathrm{M}$ sodium hydroxide, $0.01 \mathrm{M}$ perchloric acid and $0.09 \mathrm{M}$ sodium perchlorate in aqueous solutions were prepared as usual. An STZ stock solution $(0.1 \mathrm{M})$ was prepared by weighing directly in pure ethanol because it is insoluble in water, slightly soluble in ethanol (96\%), in chloroform and in ether. The working solutions (0.001 M) were prepared by accurate dilution using the same solvent.

\subsection{Procedure}

\subsubsection{Potentiometric Studies}

This is based an the method of Irving and Rossoti equations [23]. For binary and ternary systems, the following solutions were prepared and titrated against $0.1 \mathrm{M}$ of standared $\mathrm{CO}_{2}$-free $\mathrm{NaOH}$ solution at $25^{\circ} \mathrm{C} \pm 0.1^{\circ} \mathrm{C}$ :

(a) $0.01 \mathrm{M} \mathrm{HClO}_{4}+0.09 \mathrm{M} \mathrm{NaClO}_{4}$.

(b) Solution (a) + 0.001 M STZ.

(c) Solution (b) $+0.001 \mathrm{M}$ metal ion.

(d) Solution (a) + 0.001 M Gly.

(e) Solution (d) + 0.001 M metal ion.

(f) Solution (a) + 0.001 M STZ + 0.001 M Gly + 0.001 M metalion.

In all titrations, the total volume was maintained constant at $50 \mathrm{~mL}$ and different ionic strength of $\mathrm{NaClO}_{4}$ in $25 \%$ (v/v) aqueous ethanol solution.

\subsubsection{Conductometric Studies}

It was carried out at room temperature by titrating $25 \mathrm{~mL}$ of $0.001 \mathrm{M}$ of each metal ion with $0.01 \mathrm{M}$ of each ligand solution in $0.5 \mathrm{~mL}$ increment. Correction for the dilution effect is performed by multiplying the values of specific conductance by a factor $(25+\mathrm{V}) / 25$, where $\mathrm{V}$ is the volume of the titrant added.

\section{Results and Discussion}

\subsection{Proton-STZ System}

All $\mathrm{pH}$ measurements were performed at $25^{\circ} \mathrm{C} \pm 0.1^{\circ} \mathrm{C}$. The medium was aqueous acid and ionic strength $0.1 \mathrm{M} \mathrm{NaClO}_{4}$. For binary complexes studies, three types of mixtures (with total volume $50 \mathrm{~mL}$ for each) were used; (a) free acid, (b) STZ (as ligand) and (c) chelate produced from individual reaction of STZ with different metal ions; $\mathrm{Ti}(\mathrm{II}), \mathrm{Zr}(\mathrm{IV}), \mathrm{Sr}(\mathrm{II}), \mathrm{Al}(\mathrm{III}), \mathrm{Cr}(\mathrm{III}), \mathrm{Fe}(\mathrm{III})$, $\mathrm{Th}(\mathrm{IV}), \mathrm{Pb}(\mathrm{II}), \mathrm{La}(\mathrm{III})$ and $\mathrm{Co}(\mathrm{II})$. As shown in Figure 1, mixtures $\mathrm{a}, \mathrm{b}$ and $\mathrm{c}$ 


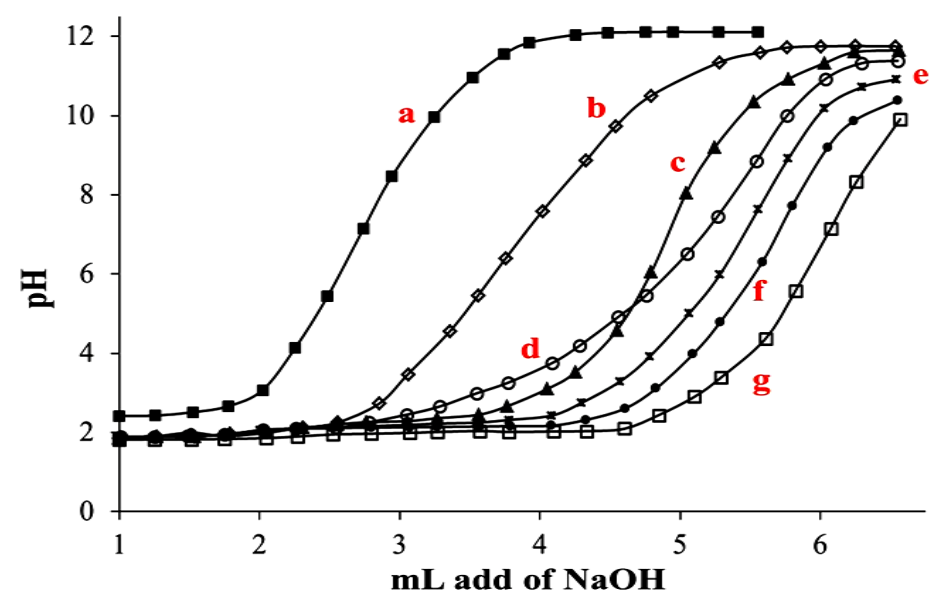

Figure 1. Representative potentiometric titration curve of STZ at $0.1 \mathrm{M} \mathrm{NaClO}_{4}$ and $25 \pm$ $0.1^{\circ} \mathrm{C}$ : (a) $0.01 \mathrm{M} \mathrm{HClO}_{4}$; (b) a + 0.001 M STZ; (c) b + 0.001 M Sr(II); (d) b + $0.001 \mathrm{M}$ $\mathrm{Pb}(\mathrm{II}) ;(\mathrm{e}) \mathrm{b}+0.001 \mathrm{M} \mathrm{Co}(\mathrm{II}) ;(\mathrm{f}) \mathrm{b}+0.001 \mathrm{M} \mathrm{Al}(\mathrm{III}) ;$ and (g) b + 0.001 M Fe(III).

were individually titrated against standard alkali and the plots of $\mathrm{pH}$ versus volume of alkali gave the titration curves.

$$
\bar{n} H=Y+\frac{\left(V_{1}-V_{2}\right)\left(N^{\circ}+E^{\circ}\right)}{\left(V_{\circ}+V_{1}\right) T c L^{\circ}}
$$

where $V_{2}$ and $V_{1}$ are the volumes of alkali required to reach the same $\mathrm{pH}$ in acid and ligand titration curves. $T c L^{\circ}$ The total ligand concentration $Y$ is the total number of protons free attached to the ligand molecule, $N$ is the normality of the alkali, $E$ is the initial concentration of the free acid and $V_{0}$ is the total volume of the titrated solution. The titration curves were used to evaluate $\bar{n} H$ (average number of protons associated with STZ); calculations of proton ligand association constants were carried out by plotting a graph of $\bar{n} H$ against $\mathrm{pH}$, as we can see in Figure 2. The concentrations were: $T c L^{\circ}=0.001 \mathrm{M}, T c M^{\circ}=0.001$ M. From these data, the proton-ligand and metal-ligand stability constants were obtained as in Table 1. The maximum numbers of protons that can be released from STZ are two protons in the titration with diluted base $(0.1 \mathrm{M})$ in the range of $\mathrm{pH} 2.20-11.20$. STZ behaves as dibasic acid $\left[\mathrm{H}_{2}-\mathrm{STZ}\right]$. The acid-base properties of STZ in $25 \%(\mathrm{v} / \mathrm{v}) \mathrm{EtOH}$ medium at different ionic strengths of $\mathrm{NaClO}_{4}(\mathrm{I}$ $=0.1,0.2,0.3,0.4$ and $0.5 \mathrm{M})$ indicate that one proton from the protonated amino group $\left(\mathrm{NH}_{2} \rightarrow \mathrm{NH}_{3}^{+}\right)$was deprotonated in the $\mathrm{pH}$ range (3.63 - 4.95).

The ionic strength has an important effect in the electrolytic solutions. It also offers ionic atmosphere, which impacts the stability constant of metal complexes. No precipitates produced, indicating that there was no propensity to form hydroxo complexes as the number of moles of $\mathrm{NaOH}$ consumed was equivalent to the number of moles of $\mathrm{NaClO}_{4}$.

It is observed that $\log k_{a}$ values inversely proportional with the concentration of ionic strength.

The second site is the dissociation of proton in the amino group (NH) in $\mathrm{pH}$ range $\left(7.10\right.$ - 9.40). The values of $\log K_{1}^{H}$ and $\log K_{2}^{H}$ (the first and second 


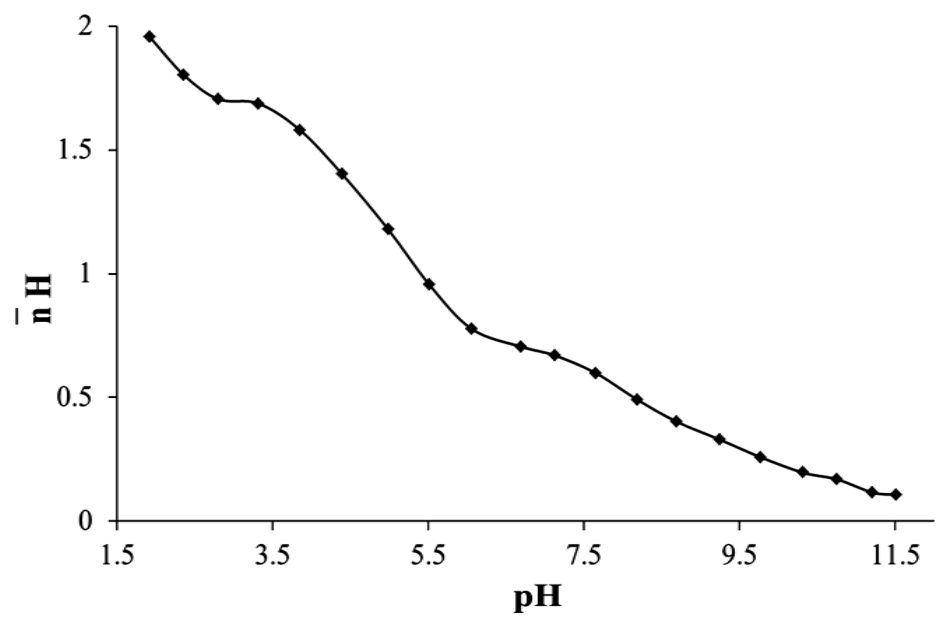

Figure 2. Representative potentiometric constant curves of STZ at $0.1 \mathrm{M} \mathrm{NaClO}_{4}$ and 25 $\pm 0.1^{\circ} \mathrm{C}$.

proton formation constants of STZ, respectively) are the $\mathrm{pH}$ values corresponding to $\bar{n} H=0.5$ and 1.5 , respectively. The values of $\log K_{1}^{H} \quad(7.20)$ and $\log K_{2}^{H} \quad(3.80)$ are tabulated in Table 1 . However, the reaction mechanism is show as follow:

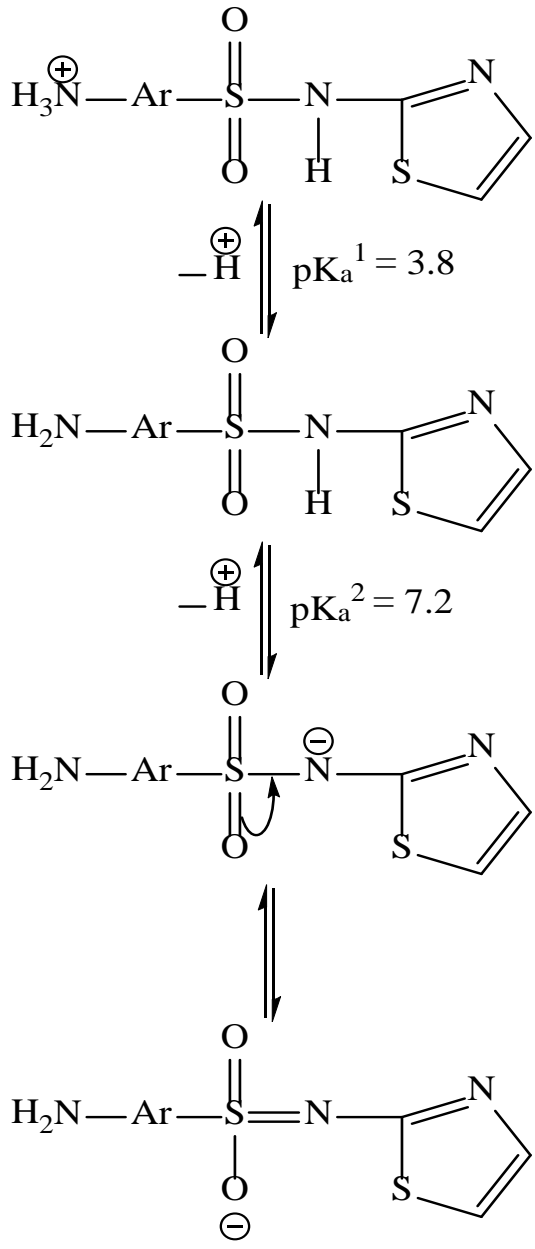


Table 1. Formation constants of STZ and stability constants of metal ion complexes at 0.1 $\mathrm{M} \mathrm{NaClO}{ }_{4}$ and $25^{\circ} \mathrm{C} \pm 0.1^{\circ} \mathrm{C}$.

\begin{tabular}{cccc}
\hline Metal Ion & $\log K_{1}(\mathrm{M}: \mathrm{L})^{*}$ & $\log K_{2}(\mathrm{M}: \mathrm{L})^{*}$ & $\log K_{3}(\mathrm{M}: \mathrm{L})^{*}$ \\
\hline $\mathrm{H}^{+}$ & 7.20 & 3.80 & --- \\
$\mathrm{Al}(\mathrm{III})$ & $6.85(1: 1)$ & $4.82(1: 2)$ & $1.61(1: 3)$ \\
$\mathrm{Pb}(\mathrm{II})$ & $4.85(1: 1)$ & $2.85(1: 2)$ & --- \\
$\mathrm{Co}(\mathrm{II})$ & $7.65(1: 1)$ & --- & --- \\
$\mathrm{Fe}(\mathrm{III})$ & $8.85(1: 1)$ & $6.45(1: 2)$ & --- \\
$\mathrm{Ti}(\mathrm{II})$ & $7.25(1: 1)$ & --- & -- \\
$\mathrm{La}(\mathrm{III})$ & $6.05(1: 1)$ & --- & --- \\
$\mathrm{Cr}(\mathrm{III})$ & $5.64(1: 1)$ & --- & --- \\
$\mathrm{Sr}(\mathrm{II})$ & $5.45(1: 1)$ & $3.49(1: 2)$ & -- \\
$\mathrm{Th}(\mathrm{IV})$ & $4.47(1: 1)$ & $3.24(1: 2)$ & $2.50(1: 3)$ \\
$\mathrm{Zr}(\mathrm{IV})$ & $7.05(1: 1)$ & $4.93(1: 2)$ & \\
\hline
\end{tabular}

${ }^{\star}$ These ratios are from potentiometric and conductometric methods.

\subsection{Binary Metal-STZ Systems}

The formation curves of the complexation equilibrium as shown in Figure 3 is obtained by plotting the degree of the complex formation $(\bar{n})$ against the negative logarithm of the concentration of non-protonated ligand $(p L)$ using the Irving and Rossotti equations [23]. From these formation curves, the values of stability constants listed in Table 1 were determined using the half-integral method [23]. The obtained results shows that both $\mathrm{Al}(\mathrm{III})$ and $\mathrm{Zr}(\mathrm{IV})$ ions forms (1:1), (1:2) and (1:3) metal to ligand complexes. Also, some metal ions viz; $\operatorname{Zr}(\mathrm{IV})$, $\mathrm{Sr}(\mathrm{II}), \mathrm{Al}(\mathrm{III}), \mathrm{Fe}(\mathrm{III}), \mathrm{Th}(\mathrm{IV})$ and $\mathrm{Pb}(\mathrm{II})$ forms (1:1) and (1:2) metal to ligand complexes, but in the case of $\mathrm{Co}(\mathrm{II}), \mathrm{Cr}(\mathrm{III}), \mathrm{Ti}(\mathrm{II})$ and $\mathrm{La}(\mathrm{III})$ only one complex (1:1) metal to ligand was formed. This may be due to the nature of metal ion, concentration of ligand and ionic strength.

$$
\begin{gathered}
\bar{n}=\frac{\left(V_{3}-V_{2}\right)\left(N^{\circ}+E^{\circ}\right)}{\left(V_{\circ}+V_{2}\right) \bar{n}_{A} T c M^{\circ}} \\
p L=\log \left[\frac{1+\beta_{1}\left[\mathrm{H}^{+}\right]+\beta_{2}\left[\mathrm{H}^{+}\right]^{2}}{\left(T c L^{\circ}-\bar{n} T c M^{\circ}\right)} \times \frac{V_{\circ}+V_{3}}{V_{\circ}}\right]
\end{gathered}
$$

where $T \mathrm{~cm}$ denotes the total concentration of metal present in solution, $\beta$ is the proton ligand stability constant, the other terms have their usual meaning as mentioned before. The stability constants of the complexes formed with STZ were listed in Table 1 in the order of stability of the different binary complexes formed between STZ and the metal ions investigated in this study, is in the expected Irving-Williams order [23]:

$$
\begin{aligned}
& \mathrm{Fe}(\mathrm{III})>\mathrm{Co}(\mathrm{II})>\mathrm{Ti}(\mathrm{II})>\mathrm{Zr}(\mathrm{IV})>\mathrm{Al}(\mathrm{III})>\mathrm{La}(\mathrm{III}) \\
& >\mathrm{Cr}(\mathrm{III})>\mathrm{Sr}(\mathrm{II})>\mathrm{Pb}(\mathrm{II})>\mathrm{Th}(\mathrm{IV})
\end{aligned}
$$




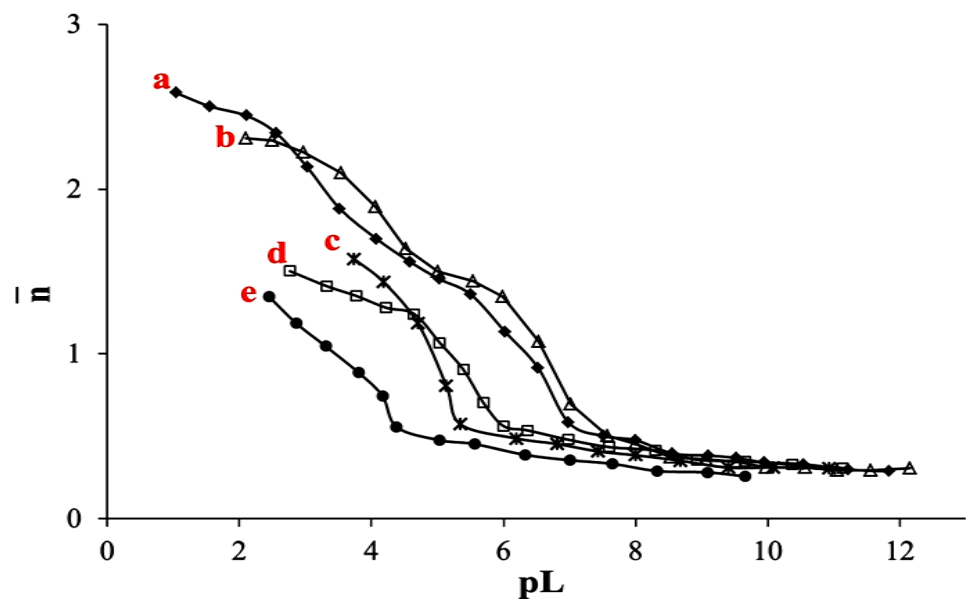

Figure 3. Representative formation curves of binary metal ion complexes with STZ at I = $0.1 \mathrm{MNaClO}_{4}$ : (a) $\mathrm{Zr}$ (IV); (b) $\mathrm{Ti}(\mathrm{II})$; (c) $\mathrm{Sr}$ (II); (d) $\mathrm{La}$ (III) and (e) Th(IV).

STZ behavior may be based on the bidentate nature which coordinates through the oxygen atom of sulphonamide group and a sulphur atom in the thiazole ring, forming stable six-membered chelate ring:<smiles>[Y4]O[SH](=O)(Nc1nccs1)[Al]N</smiles>

Ratio (1:1) metal: ligand

Also, the study of ionic strength effect on the stability constant of STZ with $\mathrm{Al}(\mathrm{III}), \mathrm{Th}(\mathrm{IV}), \mathrm{Cr}(\mathrm{III}), \mathrm{Pb}(\mathrm{II})$ and $\mathrm{Zr}(\mathrm{IV})$ metal ions in aqueous solution at $25^{\circ} \mathrm{C} \pm 0.1^{\circ} \mathrm{C}$ was discussed. The relation between $\log K_{1}$ and the ionic strength is shown in Figure 4. As we can see, the stability constants of metal-ligand complex (1:1) were decreased as the ionic strength increase.

\subsection{Conductometric Titration of STZ}

The conductometric analysis shows a greater use in tracing the complex formation. This method finds its useful application as a sensitive tool to test for decimal variations in ionic radii of transition metal ions investigated. The conductometric analysis is based on changes in the electrical conductivity values of solutions as a result of complex formation. These changes depend on the number of ions present, and their mobility's. Conductivity measurements are employed to trace the different types of chelate species formed between metal ions and STZ. Figure 5 shows the conductometric titration curve for the binary ligand system containing $\mathrm{Ti}(\mathrm{II}), \mathrm{Zr}(\mathrm{IV}), \mathrm{Sr}(\mathrm{II}), \mathrm{Al}(\mathrm{III}), \mathrm{Cr}(\mathrm{III}), \mathrm{Fe}(\mathrm{III}), \mathrm{Th}(\mathrm{IV}), \mathrm{Pb}(\mathrm{II})$, $\mathrm{La}(\mathrm{III})$ and $\mathrm{Co}$ (II) ions. As can be seen, an initial decrease in conductance and a minimum at (1:1).This may be due to the neutralization of $\mathrm{H}^{+}$ions resulting from the formation of the (M (STZ)) complex. Furthermore, the conductance 


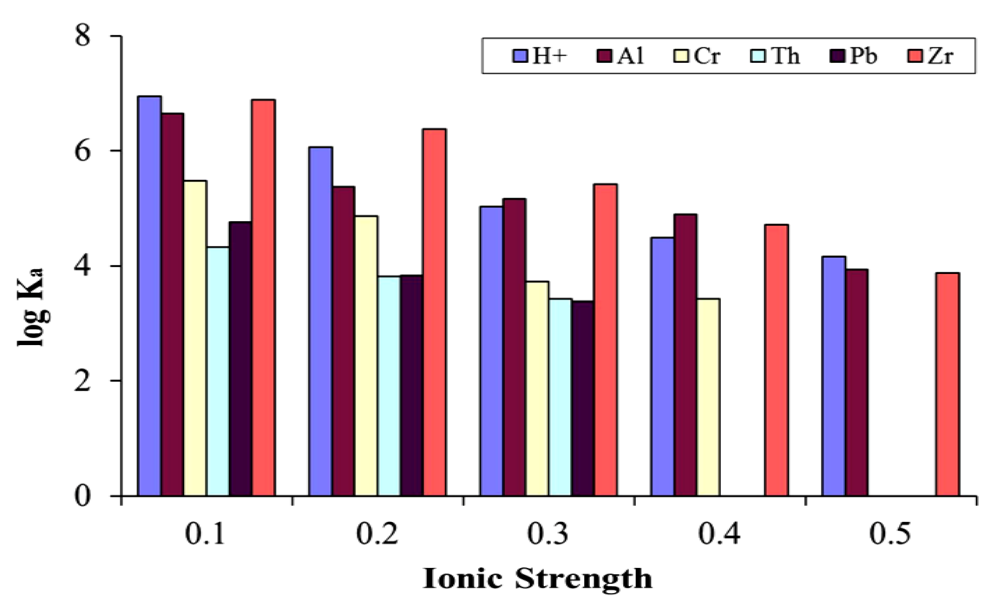

Figure 4. Effect of ionic strength on the stability constants of STZ with metal ions.

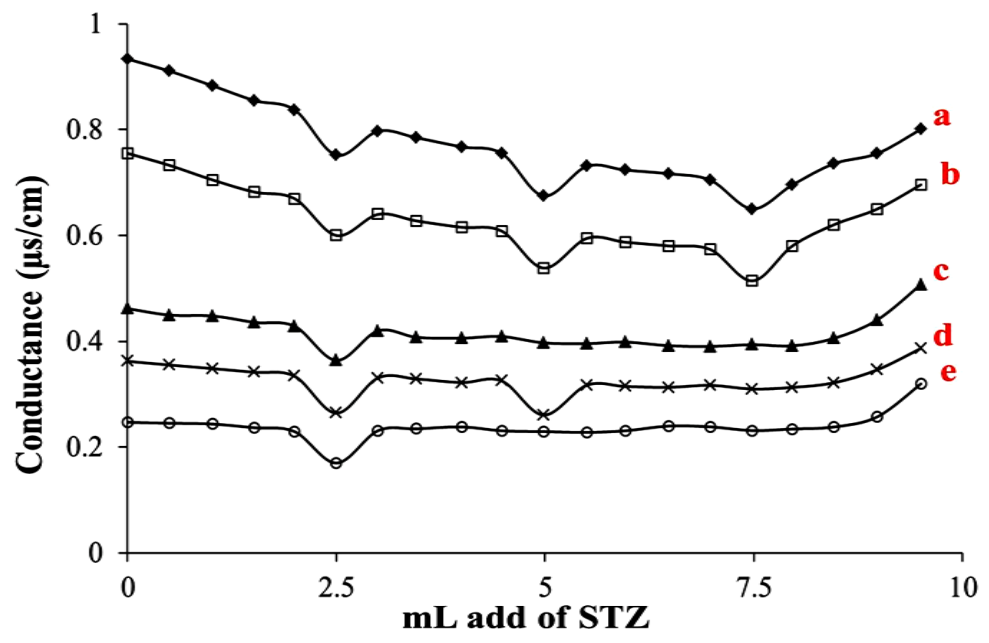

Figure 5. Representative conductometric titration curves of $25 \mathrm{~mL} 0.001 \mathrm{M}$ metal ions with 0.001 M STZ: (a) Al(III); (b) $\mathrm{Zr}(\mathrm{IV})$; (c) $\mathrm{Co}(\mathrm{II})$; (d) $\mathrm{Pb}$ (II) and (e) $\mathrm{Cr}$ (III).

increases slightly between (1:1), (1:2) and/or (1:3), probably due to the formation of the binary ligand complex and the release of $\mathrm{H}^{+}$ions from STZ.

\subsection{Species Distribution Diagrams of STZ}

Distribution curves of $\mathrm{STZ}$ at $\mathrm{I}=0.01 \mathrm{M} \mathrm{NaClO}_{4}$ shown in Figure 6 observe the $\mathrm{pH}$ range $(2.20-4.80)$ the major species is $\alpha_{\circ}\left(\mathrm{H}_{2}-\mathrm{STZ}\right)$ and in the $\mathrm{pH}$ range $(4.80$ - 6.00) the major one is $\alpha_{1}\left(\mathrm{H}-S T Z^{-1}\right)$, but $\alpha_{2}\left(\mathrm{STZ}^{-2}\right)$ is major in the $\mathrm{pH}$ range (6.00 - 11.40). The species distribution curves can be obtained by plotting the mole fraction of metal species and $\mathrm{pH}$. The curves are depicted in Figure 7. The analysis of these diagrams reveals that at low $\mathrm{pH}$ value, most of the metal ions are often present as free ions. This indicated that no complex occur in the acidic medium. On increasing the concentration of the ligand by increasing the $\mathrm{pH}$ of the solution during the titration, the mole fraction of the free metal ion tends to decrease, while that of ML species tend to develop at moderately acidic media. However, the value of $\log K_{1}>\log K_{2}$ indicates that there will be an appreciable 


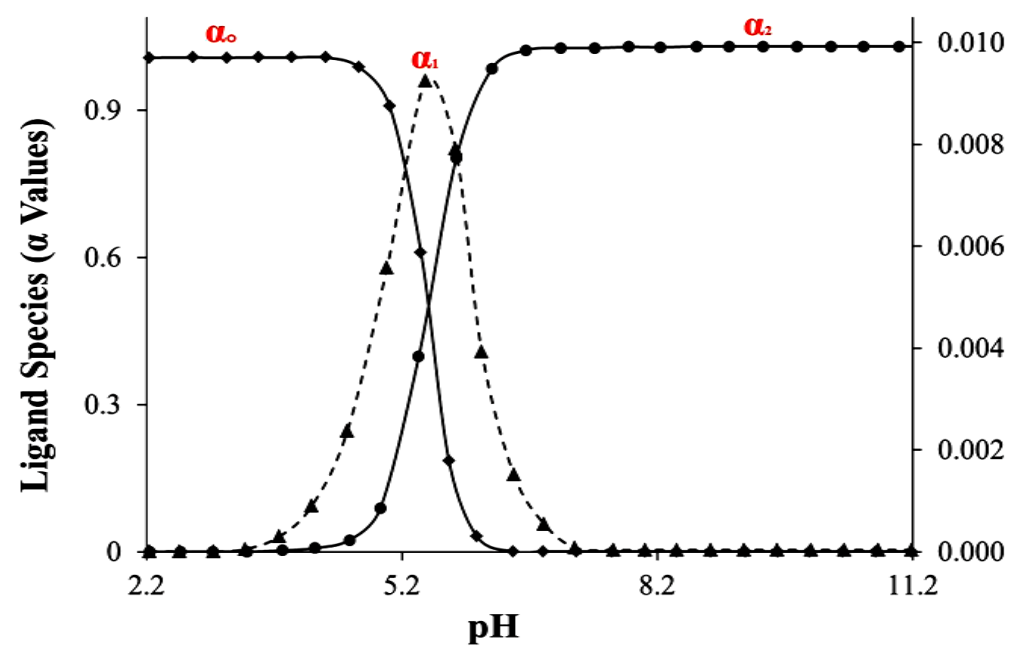

Figure 6. Ionic equilibria of STZ in different $\mathrm{pH}$ 's range.

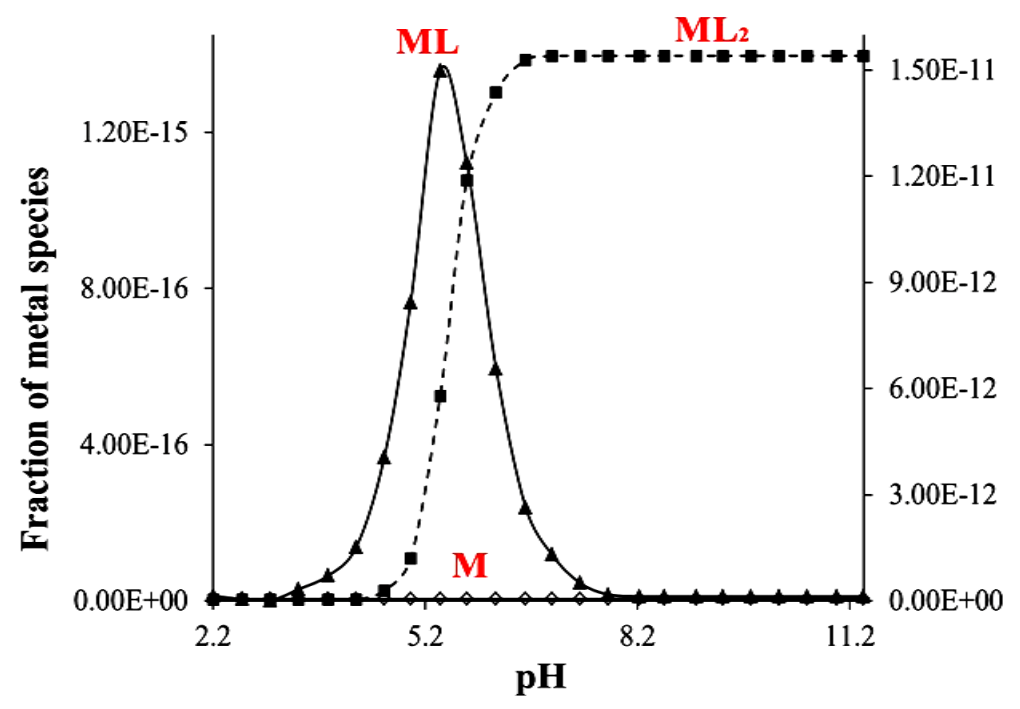

Figure 7. Representative ionic equilibria of $\mathrm{Al}(\mathrm{III})-\mathrm{STZ}$ in different $\mathrm{pH}$ 's range.

concentration of ML species in this $\mathrm{pH}$ region. Further increasing the $\mathrm{pH}$ of the solution, the essential change is the increase in ML2 concentration with decrease in ML. Above this region almost the entire metal ion remains in the form of ML or $\mathrm{ML}_{2}$ species on increasing the $\mathrm{pH}$ of the solution. Some fraction species at intersection points and maximum $\mathrm{pH}$, complexes are represented.

\subsection{Ternary Systems}

The stability constants for the ternary systems were computed from titrations in which the concentrations of metal ions: STZ: Gly were kept in the ratio 1:1:1, listed in Table 2. The experimental data shown in Figure 8 reveal that the formation of the ternary complex M (STZ) (Gly) shifts the buffer region of the ligands to lower $\mathrm{pH}$ values, which indicates that the ternary complex is more stable than the binary complex. The horizontal distance between curves $e$ and $f$ 


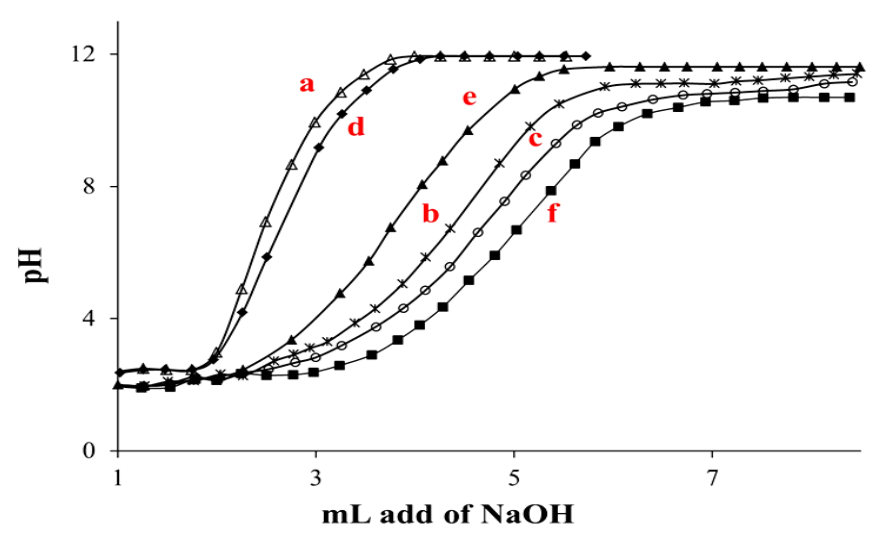

Figure 8. Representative potentiometric titration curve for $\mathrm{Al}$ (III)-STZ-Gly system, at $0.1 \mathrm{M} \mathrm{NaClO}_{4}$ and $25^{\circ} \mathrm{C} \pm 0.1^{\circ} \mathrm{C}$ : (a) $0.01 \mathrm{M} \mathrm{HClO}_{4}$; (b) a + $0.001 \mathrm{M} \mathrm{STZ}$; (c) b + $0.001 \mathrm{M}$ $\mathrm{Al}$ (III); (d) a + 0.001 M Gly; (e) d + 0.001 M Al (III) and (f) a + 0.001 M STZ + 0.001 M Gly $+0.001 \mathrm{M} \mathrm{Al}(\mathrm{III})$.

Table 2. Proton ligand formation constants of STZ and stability constant of ternary complexes formed in this study at $0.1 \mathrm{M} \mathrm{NaClO}_{4}$ and $25^{\circ} \mathrm{C} \pm 0.1^{\circ} \mathrm{C}$.

\begin{tabular}{|c|c|c|c|c|c|}
\hline \multirow{2}{*}{ Metal Ions } & M (STZ) & M (STZ) & M (Gly) & \multirow{2}{*}{$\log K_{\mathrm{M}(\mathrm{STZ})(\mathrm{Gly})}^{\mathrm{M}(\mathrm{SZZ})}$} & \multirow{2}{*}{$\Delta \log K$} \\
\hline & $\log K_{1}^{H}$ & $\log K_{2}^{H}$ & $\log K_{3}^{H}$ & & \\
\hline $\mathrm{H}^{+}$ & 7.20 & 3.80 & 10.30 & --- & --- \\
\hline $\mathrm{Fe}$ (III) & 8.85 & 6.45 & 6.34 & 3.35 & -2.99 \\
\hline $\mathrm{Al}$ (III) & 6.85 & 4.82 & 4.94 & 9.23 & +4.29 \\
\hline $\mathrm{Sr}$ (II) & 5.45 & 3.49 & 8.34 & 6.09 & -2.25 \\
\hline Th (IV) & 4.47 & 3.24 & 5.94 & 8.15 & +2.21 \\
\hline $\mathrm{Pb}(\mathrm{II})$ & 4.85 & 2.85 & 9.14 & 8.93 & -0.21 \\
\hline $\mathrm{La}$ (III) & 6.05 & --- & 6.94 & 5.76 & -1.18 \\
\hline $\mathrm{Ti}$ (II) & 7.25 & --- & 9.54 & 9.13 & -0.41 \\
\hline $\mathrm{Zr}(\mathrm{IV})$ & 7.05 & 4.93 & 8.53 & 7.47 & -1.06 \\
\hline Co (II) & 7.65 & --- & 7.14 & 4.04 & -3.10 \\
\hline $\mathrm{Cr}$ (III) & 5.64 & --- & 7.54 & 4.72 & -2.82 \\
\hline
\end{tabular}

were measured and used for the calculation of $\bar{n}_{\text {mix }}$ (average number of secondary ligand (L) molecule attach edper (M-STZ) binary complex using Equation 4:

$$
\bar{n}_{\text {mix }}=\frac{\left(V_{4}-V_{3}\right)-\left(V_{2}-V_{1}\right)\left[\left(N^{\circ}+E^{\circ}\right)+T c L^{\circ}(Y-\bar{n} H)\right]}{\left(V_{\circ}+V_{3}\right) \bar{n} H T c M^{\circ}}
$$

where $V_{1}, V_{2}, V_{3}$, and $V_{4}$ are the volumes of $\mathrm{NaOH}$ required to reach the same $\mathrm{pH}$ values for solutions of (free acid), (free acid $+\mathrm{STZ}$ ), (free acid $+\mathrm{STZ}+$ metal ion) and (free acid $+\mathrm{STZ}+$ metal ion + Gly), respectively. The difference $\left(V_{4}-V_{3}\right)-\left(V_{2}-V_{1}\right)$ can be used for the calculation of $\bar{n}_{\text {mix }}$ (average number of secondary ligand molecules associated with one $[\mathrm{M}(\mathrm{Gly})]_{n}^{+}$ion. The free sec- 
ondary ligand exponent, $p L_{m i x}$ was calculated using Equation (5):

$$
p L_{\text {mix }}=\log \left[\frac{\sum_{n=0}^{i} \beta_{n}^{H}\left(\frac{1}{10^{B}}\right)^{n}}{T c L^{\circ}-\bar{n}_{\text {mix }} T c M^{\circ}} \cdot \frac{V_{\circ}+V_{4}}{V_{\circ}}\right]
$$

According to the obtained results, the complex equilibria of M-STZ-Gly can be represented by the following scheme:

$$
\begin{gathered}
\mathrm{M}+\mathrm{STZ} \leftrightarrow \mathrm{M}(\mathrm{STZ}) \\
\mathrm{M}(\mathrm{STZ})+\mathrm{Gly} \leftrightarrow \mathrm{M}(\mathrm{STZ})(\mathrm{Gly}) \\
K_{\mathrm{M}(\mathrm{STZ})(\mathrm{Gly})}^{\mathrm{M}(\mathrm{STZ})}=\frac{[\mathrm{M}(\mathrm{STZ})(\mathrm{Gly})]}{[\mathrm{M}(\mathrm{STZ})][\text { Gly }]}
\end{gathered}
$$

In order to compare the stabilities of the ternary complex species with those of the parent binary complexes, the $\Delta \log K$ value (the difference between the stabilities of the binary and the ternary complexes) were determined. The parameter $\Delta \log K$ is determined by Equation (9):

$$
\Delta \log K=\log K_{\mathrm{M}(\mathrm{STZ})(\mathrm{Gly})}^{\mathrm{M}(\mathrm{STZ})}-\log K_{\mathrm{M}(\mathrm{Gly})}^{\mathrm{M}}
$$

It was found that the difference was positive in terms of stability and showed a statistical increase in the value of stability constants of the mixed ligand complex. As shown in Table 2, the values of ternary stability constants are found to decrease in this order: $\mathrm{Al}(\mathrm{III})>\mathrm{Ti}(\mathrm{II})>\mathrm{Pb}(\mathrm{II})>\mathrm{Th}(\mathrm{IV})>\mathrm{Zr}(\mathrm{IV})>\mathrm{Sr}(\mathrm{II})>$ $\mathrm{La}(\mathrm{III})>\mathrm{Cr}(\mathrm{III})>\mathrm{Co}(\mathrm{II})>\mathrm{Fe}(\mathrm{III})$

Formation curves corresponding to the various metal ions-STZ-Gly systems were obtained by plotting $\bar{n}_{\text {mix }}$ vs. $p L_{\text {mix }}$ the results are shown in Figure 9. Values of the formation constant of the STZ ternary complexes (tabulated in Table 2) shows that, the metal ions such as $\mathrm{Al}(\mathrm{III})$ and $\mathrm{Th}(\mathrm{IV})$ used in M-STZGly ternary complexes are more stable than the (1:1) M-STZ binary complex and

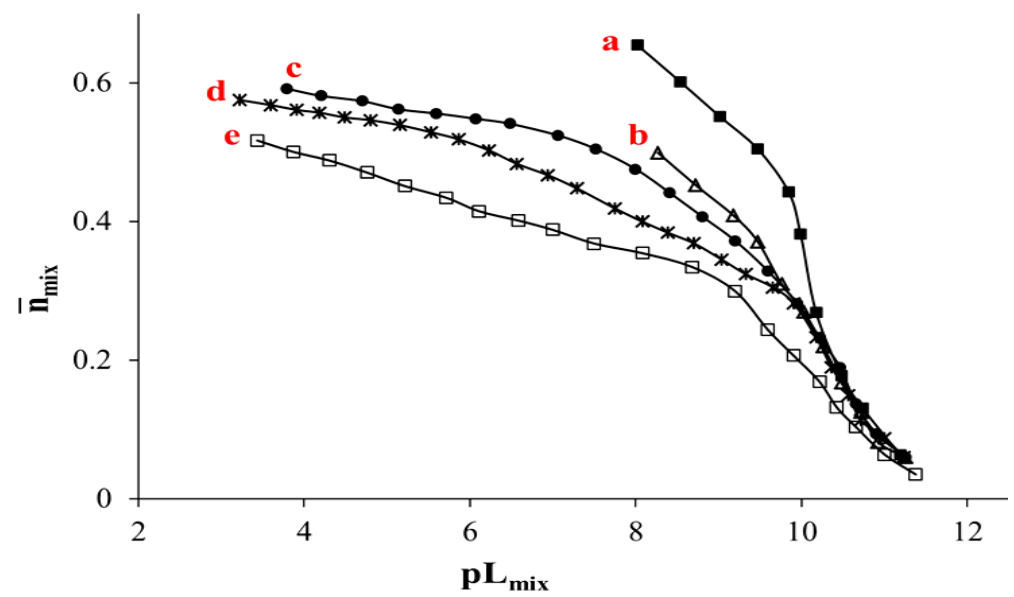

Figure 9. Representative M-STZ-Gly formation curves: (a) $\mathrm{Al}(\mathrm{III})$; (b) $\mathrm{Pb}$ (II); (c) $\mathrm{Zr}$ (IV); (d) $\mathrm{Th}(\mathrm{IV})$ and (e) $\mathrm{Sr}(\mathrm{II})$. 
the (1:1) M-Gly binary complexes. Thus, the (1:1) M-STZ complex has a greater tendency toward combination with Gly molecule to form ternary complexes. But some metal ions viz; $\mathrm{Fe}(\mathrm{III}), \mathrm{Cr}(\mathrm{III}), \mathrm{La}(\mathrm{III})$ and $\mathrm{Co}$ (II) forms less stable ternary complexes with STZ and Gly than the other corresponding binary complexes of them. Therefore, the binary complexes of the primary ligand (STZ) with these metal ions may be at odds with the combination with the Gly molecule to form ternary complexes. On the other hand, some metal ions like, $\mathrm{Pb}$ (II), $\mathrm{Sr}$ (II), $\mathrm{Ti}$ (II) and $\mathrm{Zr}(\mathrm{IV})$ have up-normal values. This behavior may be interpreted on the basis of statistical considerations and the nature of species formed in the solution.

\section{Conclusion}

In the present article, the protonation and complex formation constants of binary and ternary complexes of sulphathiazole end glycine with different metal ions were calculated using potentiometric and conductometric Methods in $25^{\circ} \mathrm{C}$ $\pm 0.1^{\circ} \mathrm{C}$ and $\mathrm{I}=0.1 \mathrm{M} \mathrm{NaClO}_{4}$ in $25 \%$ (v/v) pure ethanol-water medium. The order of stability of the formed binary and ternary complexes was presented. The experimental $\Delta \log K$ parameters were calculated, showing the effect of the bound primary ligand toward an incoming secondary ligand. $\Delta \log K$ values are positive; this indicates that the ternary complexes are more stable than the corresponding binary ones. The reported data in this study will make an important contribution to the literature.

\section{Acknowledgements}

This work was supported by the Institute of Research and Consulting Studies at Umm Al-Qura University (Project ID: 43603042).

\section{References}

[1] Domagk, G. (1935) A Contribution to the Chemotherapy of Bacterial Infections. Deutsche Medizinische Wochenschrift, 6, 250-253.

https://doi.org/10.1055/s-0028-1129486

[2] Thiele-Bruhn, S.J. (2003) Pharmaceutical Antibiotic Compounds in Soils-A Review. Journal of Plant Nutrition and Soil Science, 166, 145-167. https://doi.org/10.1002/jpln.200390023

[3] Zani, F. and Vicini, P. (1998) Antimicrobial Activity of Some 1,2-Benzisothiazoles Having a Benzenesulfonamide Moiety. Archiv der Pharmazie, 331, 219-223. https://doi.org/10.1002/(SICI)1521-4184(199806)331:6<219::AID-ARDP219>3.0.C $\underline{\mathrm{O} ; 2-\mathrm{U}}$

[4] Maren, T. (1976) Relations between Structure and Biological Activity of Sulfonamides. Annual Review of Pharmacology and Toxicology, 16, 309-327. https://doi.org/10.1146/annurev.pa.16.040176.001521

[5] Supuran, C.T., Scozzafava, A., Jurca, B.C. and Iiies, M.A. (1998) Carbonic Anhydrase Inhibitors-Part 49: Synthesis of Substituted Ureido and Thioureido Derivatives of Aromatic/Heterocyclic Sulfonamides with Increased Affinities for Isozyme I. European Journal of Medicinal Chemistry, 33, 83-93. https://doi.org/10.1016/S0223-5234(98)80033-0

[6] Blasco, F., Perelló, L., Latorre, J., Borrás, J., Garciá-Granda, S. and Inorg, J. (1996) 
Cobalt(II), Nickel(II), and Copper(II) Complexes of Sulfanilamide Derivatives: Synthesis, Spectroscopic Studies, and Antibacterial Activity. Crystal Structure of [Co(sulfacetamide $)_{2}(\mathrm{NCS})_{2}$ ]. Journal of Inorganic Biochemistry, 61, 143-154. https://doi.org/10.1016/0162-0134(95)00053-4

[7] Topacli, A. and Kesimli, B. (2001) Investigation on Sulfanilamide and Its Interaction with Some Metals and Lincomycin by Infrared Spectroscopy. Spectroscopy Letters, 34, 513-526. https://doi.org/10.1081/SL-100105097

[8] Karthikeyan, G., Mohanraj, K., Elango, K.P. and Girishkumar, K. (2006) Synthesis and Spectral Characterization of lanthanide Complexes with Sulfamethoxazole and Their Antibacterial Activity. Russian Journal of Coordination Chemistry, 32, 380-385. https://doi.org/10.1134/S1070328406050113

[9] Golzar, H. (2013) Synthesis and Characterisation of Cobalt Complex of Sulfathiazole with Acetic acid. Journal of Saudi Chemical Society, 17, 253-257.

https://doi.org/10.1016/j.jscs.2011.04.002

[10] Bellú, S., Hure, E., Trapé, M., Trossero, C., Molina, G., Drogo, C., Williams, P.A.M., Atria, A.M., Acevedo, J.C.M., Zacchino, S., Sortino, M., Campagnoli, D. and Rizzotto, M. (2005) Synthesis, Structure and Antifungal Properties of Co(II)-Suifathiazolate Complexes. Polyhedron, 24, 501-509.

https://doi.org/10.1016/j.poly.2004.12.017

[11] Henderson, W., McCaffrey, L.J., Dinger, M.B. and Nicholson, B.K. (1998) Platinum (II) and Palladium (II) Complexes Derived from the Anion of Sulfathiazole [4,2]; Crystal Structure of Cis-[Pt $\left.(\mathrm{STZ})_{2}\left(\mathrm{PPh}_{3}\right)_{2}\right] .3 \mathrm{CHCl}_{3}$. Polyhedron, 17, 3137-3144. https://doi.org/10.1016/S0277-5387(98)00078-3

[12] Bellú, S., Hure, E., Trapé, M., Rizzotto, M., Sutich, E., Sigrist, M. and Moreno, V. (2003) The Interaction between Mercury(II) and Sulfathiazole. Quimica Nova, 26, 188-192. https://doi.org/10.1590/S0100-40422003000200008

[13] Nunes, B., de Paiva, F., Cuin, A., Lustri, R. and Corbi, P. (2015) Silver Complexes with Sulfathiazole and Sulfamethoxazole: Synthesis, Spectroscopic Characterization, Crystal Structure and Antibacterial Assays. Polyhedron, 85, 437-444. https://doi.org/10.1016/j.poly.2014.09.010

[14] Daniele, P., Zerbinati, O., Zelano, V. and Ostacoli, G. (1998) Thermodynamic and Spectroscopic Study of Copper(II)-glycyl-L-histidylglycine Complexes in Aqueous Solution. Journal of the Chemical Society, Dalton Transactions, 10, 2711-2715.

[15] Amrallah, H., Abdalla, A. and El-Haty, Y. (1998) Mixed Ligand Complexes of Benzimidazole and Pyrimidine Hydroxyazo Dyes with Some Transition Metals and Glycine, DL-Alanine or DL-Leucine. Talanta, 46, 491-500.

https://doi.org/10.1016/S0039-9140(97)00218-X

[16] Inci, D. and Aydin, R. (2017) Potentiometric Studies on Complexation of Cu(II) Ion with Methyl/Nitro-Substituted 1,10-Phenanthrolines and Selected Amino Acids. Journal of Solution Chemistry, 46, 124-138. https://doi.org/10.1007/s10953-016-0551-1

[17] Rossotti, F. and Rossotti, H. (1961) The Determination of Stability Constants and Other Equilibrium Constants in Solution. 4th Edition, McGraw-Hill Book Company Inc., New York.

[18] Kirschner, S., Wei, Y., Francis, D. and Bergam, J. (1966) Anticancer and Potential Antiviral Activity of Complex Inorganic Compounds. Journal of Medicinal Chemistry, 9, 369-372. https://doi.org/10.1021/jm00321a026

[19] Mohamed, A., Wadood, A. and Farghaly, O. (2002) Potentiometric and Spectrofluorimetric Studies on Complexation of Tenoxicam with Some Metal Ions. Journal of 
Pharmaceutical and Biomedical Analysis, 28, 819-826.

https://doi.org/10.1016/S0731-7085(01)00691-4

[20] Abdel Gaber, A., Farghaly, O., Ghandour, M. and El-Said, H. (2000) Potentiometric Studies on Some Cephalosporin Complexes. Monatshefte für ChemielChemical Monthly, 131, 1031-1038. https://doi.org/10.1007/s007060070034

[21] Yousef, W., Alenezi, K., Naggar, A., Hassan, T., Bortata, S. and Farghaly, O. (2017) Potentiometric and Conductometric Studies on Complexes of Folic Acid with Some Metal Ions. International Journal of Electrochemical Science, 12, 1146-1156. https://doi.org/10.20964/2017.02.06

[22] Scott, W. and Furman, H. (1962) Standard Methods of Chemical Analysis. 6th Edition, Van Nostrand, New York.

[23] Irving, H. and Williams, R.J.P. (1948) Order of Stability of Metal Complexes. Nature, 162, 746-747. https://doi.org/10.1038/162746a0 